\title{
Pengaruh Pengawasan, Kepemimpinan Dan Motivasi Kerja Terhadap Disiplin Kerja Pada Pegawai Kantor Dinas Ketahanan Pangan Dan Peternakan Provinsi Sumatera Utara
}

\author{
Nining Yustina \\ Program Studi Magister Manajemen, Universitas Muhammadiyah Sumatera Utara \\ Medan, Indonesia \\ Zulaspan Tupti \\ Program Studi Magister Manajemen, Universitas Muhammadiyah Sumatera Utara \\ Medan, Indonesia
}

Koresponden: zulaspantupti@umsu.ac.id

\begin{abstract}
Abstrak The purpose of this study was to determine and analyze the effect of supervision, leadership and work motivation on the work discipline of the Office of Food Security and Animal Husbandry Office of North Sumatra Province. The approach used in this study is an associative approach. The population in this study were all employees of the Office of Food Security and Animal Husbandry of North Sumatra Province. The sample in this study used the slovin formula, totaling 68 employees of the Office of Food Security and Animal Husbandry of North Sumatra Province. Data collection techniques in this study used interview techniques, documentation studies, observation, and questionnaires. The data analysis technique in this study uses Multiple Linear Regression Analysis Test, Hypothesis Testing ( $t$ Test and F Test), and Coefficient of Determination. The data processing in this study used the SPSS (Statistical Package for the Social Sciences) software program version 24.00. The results of this study prove that supervision, leadership and work motivation have a significant effect on work discipline for employees of the Office of Food Security and Animal Husbandry of North Sumatra Province.
\end{abstract}

Kata Kunci Supervision, Leadership, Work Motivation, Work Discipline

\section{PENDAHULUAN}

Peranan Sumber Daya Manusia Merupakan salah satu faktor utama yang sangat penting dalam suatu organisasi. Pemanfaatan Sumber Daya Manusia secara efektif merupakan jalan bagi suatu organisasi untuk mempertahankan kelangsungan hidup Peserta didik dan petumbuhan dimasa yang akan datang. Dengan kata lain, keberhasilan atau kemunduran suatu peserta didik tergantung pada keahlian dan keterampilan pegawainya masing masing yang bekerja di dalamnya. Pegawai Negeri Sipil merupakan Sumber Daya Manusia seorang pendidik yang bertugas memberikan ilmu kepada peserta didik secara Profesional, jujur, adil dan merata dalam penyelenggaraan tugas Negara, pemerintahan dan pembagunan dengan landasan kesetiaan dan ketaatan kepada pancasila dan ketentuan pasal 1 Undang-undang 1945. (Risma et al., 2018) Kedudukan dan peranan pegawai Negeri Sipil di Indonesia dirasakan semakin penting untuk menyelenggarakan 


\section{JESYA}

JURNAL EKONOMI \& EKONOMI SYARIAH

Jurnal Ekonomi \& Ekonomi Syariah Vol 5 No 1, Januari 2022

E-ISSN : 2599-3410| P-ISSN : 2614-3259

DOI : https://doi.org/10.36778/jesya.v5i1.633

pemerintahan dan pembangunan dalam usaha mencapai tujuan nasionl yaitu mewujudkan peserta didik yang dimana taat yang akan membangun generasi muda Indonesia. Kedudukan dan peranannya yang penting menyebabkan Pegawai Negeri Sipil senantiasa dituntut supaya memiliki kesetiaan dan ketaatan penuh dalam menjalankan tugas-tugasnya dan memusatkan seluruh perhatian serta mengerahkan segala daya dan tenaga secara berguna dan berhasil guna (Risma et al., 2018)

Disiplin kerja adalah suatu bentuk kesadaran yang tumbuh dari diri seseorang dalam memenuhi tanggung jawab dan mentaati peraturan-peraturan yang ada dalam perusahaan. Untuk dapat mengontrol disiplin kerja pegawai diperlukan adanya pengawasan serta motivasi dari pimpinan orgnaisasi. Pengawasan sangat penting dalam meningkatkan kedisiplinan pegawai. Agar dapat mendorong kedisiplinan pegawai diperlukan adanya hubungan kerja saling menguntungkan antara pimpinan dengan pegawai. Pegawai menunjukkan tingkat kedisiplinan yang tinggi guna kemajuan organisasi, sedangkan pimpinan memberikan feedback (umpan balik) terhadap kedisiplinan pegawai yaitu dengan memberikan reward (kompensasi) terhadap pegawai yang disiplin serta punishment (hukuman) terhadap pegawai yang rendah kedisiplinannya. (Rizal \& Radiman, 2019). Pengawasan merupakan proses pengamatan dari pelaksanaan seluruh kegiatan organisasi untuk mengumpulkan data dalam usaha mengetahui ketercapaian tujuan dan kesulitan apa yang ditemui dalam pelaksanaan itu". Dengan adanya pengawasan pimpinan dapat mengetahui kegiatan-kegiatan nyata dari setiap aspek dan setiap permasalahan pelaksanaan tugas-tugas dalam lingkungan satuan organisasi yang masing-masing selanjutnya bilamana terjadi penyimpangan, maka dapat dengan segera langsung mengambil langkah perbaikan dan tindakan seperlunya sesuai dengan rencana yang telah ditetapkan sebelumnya serta peraturan perundang-undangan yang berlaku. (Hasibuan, 2016). Pertama kali pimpinan harus memberikan perhatian pada karyawan tentang pentingnya tujuan dari suatu pekerjaan agar timbul minat karyawan terhadap pelaksanaan kerja, jika telah timbul minatnya maka hasratnya menjadi kuat untuk mengambil keputusan dan melakukan tindakan kerja dalam mencapai tujuan yang di harapkan dalam pemimpin, dengan demikian karyawan akan bekerja dengan motivasi tinggi dan merasa puas terhadap hasil kerjanya. (Mangkunegara, 2014)

Tugas seorang pemimpin untuk mengawasi para karyawan yang ada dalam lingkup organisasinya dalam proses pelaksanaan pekerjaan maupun faktor-faktor yang ada dalam setiap diri individu karyawan yang menyebabkan karyawan tersebut giat dalam bekerja dan mempunyai disiplin yang tinggi dalam bekerja. Organisasi yang baik memiliki struktur organisasi dan tugas yang jelas, sehingga fungsi pengawasan yang menjadi tugas para pimpinan dapat dengan mudah dilaksanakan. (Rizal \& Radiman, 2019). Terjadinya penyimpangan mengakibatkan disiplin kerja menurun karena itu setiap kegiatan yang sedang berlangsung dalam organisasi haruslah berdasarkan fungsi-fungsi manajemen dimana salah satu diantaranya adalah fungsi pengawasan agar tujuan organisasi dapat tercapai secara efisien dan efektif. (Hasibuan, 2016). Faktor kepemimpinan juga merupakan salah satu unsur yang mempengaruhi disiplin kerja. Seorang pemimpin dibutuhkan untuk mengarahkan pegawai disiplin dalam bekerja guna mencapai tujuan organisasi, sebab mutu kepemimpinan yang terdapat dalam suatu organisasi memainkan peranan yang sangat dominan dalam keberhasilan organisasi tersebut dalam menyelenggarakan berbagai kegiatannya terutama terlihat dalam kedisplinan kerja para pegawainya (Siagian, 2014) Kepemimpinan merupakan kemampuan untuk mempengaruhi sebuah kelompok guna mencapai sebuah visi atau serangkaian tujuan yang ditetapkan (Robbins, 2012) 


\section{JESYA}

JURNAL EKONOMI \& EKONOMI SYARIAH

Jurnal Ekonomi \& Ekonomi Syariah Vol 5 No 1, Januari 2022

E-ISSN : 2599-3410 | P-ISSN : 2614-3259

DOI : https://doi.org/10.36778/jesya.v5i1.633

Keberhasilan suatu organisasi sangat bergantung pada mutu kepemimpinan yang terdapat dalam organisasi yang bersangkutan. Bahkan, kiranya dapat dikatakan bahwa mutu kepemimpinan yang terdapat dalam suatu organisasi memainkan peranan yang sangat dominan dalam keberhasilan organisasi dalam menyelenggarakan berbagai kegiatan nyata terutama terlihat dalam kinerja para pegawainya (Siagian, 2014) Motivasi adalah pemberian atau penimbulan motif atau dapat pula diartikan sebagai hal atau keadaan menjadi motif. Jadi motivasi adalah sesuatu yang menimbulkan semangat atau dorongan kerja. (Sutrisno, 2010). Motivasi menggambarkan kombinasi yang konsisten dari dorongan internal dan eksternal dalam diri seseorang yang diindikasikan dengan adanya hasrat dan minat (Susanty \& Baskoro, 2012)

Motivasi yang tepat akan memacu daya penggerak untuk menciptakan kegairahan kerja seseorang agar mereka mau bekerja sama dengan efektif dan terintegrasi dengan segala daya upayanya untuk mencapai kepuasan, selain itu motivasi dapat menjadi penyebab maupun mendukung perilaku seseorang sehingga orang tersebut berkeinginan untuk berkerja keras dan antusias untuk mencapai hasil yang optimal. Kedisiplinan merupakan salah satu fungsi operatif dari manajer. Tanpa disiplin pegawai yang baik, sulit bagi instansi pemerintahan untuk mencapai hasil yang optimal. Disiplin kerja pegawai dapat dilihat dari penyelesaian tugas dan kewajiban (Kartono, 2015). Dinas Ketahanan Pangan dan Peternakan Provinsi Sumatera Utara adalah unsur pelaksana kontroling dalam hal ketersediaan pangan dan ternak di daerah sumatera utara. Dinas Ketahanan Pangan dan Peternakan Provinsi Sumatera Utara merupakan sebuah instansi yang menghasillakan jasa non-profit (tidak berorientasi pada perolehan laba).

\section{LANDASAN TEORI}

\section{Disiplin Kinerja}

Disiplin yang baik mencerminkan besarnya rasa tanggung jawab seseorang terhadap tugas-tugas yang diberikan kepadanya. Hal ini mendorong gairah kerja, semangat kerja, dan terwujudnya tujuan perusahaan, karyawan, dan masyarakat. Oleh karena itu, setiap manajer selalu berusaha agar para bawahannya mempunyai disiplin yang baik. Untuk memelihara dan meningkatkan kedisiplinan yang baik adalah hal yang sulit, karena banyak faktor yang mempengaruhinya. Disiplin merupakan suatu sikap yang tidak dapat muncul dengan sendirinya terhadap diri karyawan, untuk melahirkan sikap disiplin maka sikap tersebut harus selalu dilatih dan diterapkan pada diri karyawan. Menurut (Afandi, 2016) disiplin kerja adalah suatu tata tertib maupun peraturan yang dibuat oleh suatu organisasi dan disahkan oleh dewan komisaris atau pemilik modal, disepakati oleh serikat pekerja dan diketahui oleh dinas tenaga kerja seterusnya orangorang tergabung dalam organisasi tunduk pada tata tertib yang ada dengan rasa senang hati, sehingga tercipta dan terbentuk melalui proses dari serangkaian perilaku yang menunjukkan nilai-nilai ketaatan, kepatuhan, keteraturan, dan ketertiban. Menurut (Hasibuan, 2016) disiplin kerja merupakan suatu bentuk kesadaran dan kesediaan seseorang menaati semua peraturan perusahaan dan norma-norma sosial yang berlaku. Sedangkan menurut.

\section{Indikator Disiplin Kerja}

Menurut (Sutrisno, 2010) meyatakan indikator disiplin kerja:

1. Taat terhadap aturan waktu.

2. Taat terhadap peraturan perusahaan.

3. Taat terhadap aturan perilaku dalam pekerjaan. 
4. Taat terhadap peraturan lainnya diperusahaan.

Berikut ini adalah penjelasan dari indikator disiplin kerja di atas

1. Taat terhadap aturan waktu.

Dilihat dari jam masuk kerja, jam pulang, dan jam istirahat yang tepat waktu sesuai dengan aturan yang berlaku di perusahaan.

2. Taat terhadap peraturan perusahaan.

Peraturan dasar tentang cara berpakaian, dan bertingkah laku dalam pekerjaan.

3. Taat terhadap aturan perilaku dalam pekerjaan.

Ditunjukkan dengan cara-cara melakukan pekerjaan-pekerjaan sesuai dengan jabatan, tugas, dan tanggung jawab serta cara berhubungan dengan unit kerja lain.

4. Taat terhadap peraturan lainnya diperusahaan.

Aturan tentang apa yang boleh dan apa yang tidak boleh dilakukan oleh para karyawan dalam perusahaan.

\section{Pengawasan}

Suatu sistem pengawasan yang baik sangat penting dan berpengaruh dalam proses pelaksanaan kegiatan, baik dalam organisasi pemerintah maupun swasta. Tujuan pengawasan adalah mengamati apa yang sebenarnya terjadi dan membandingkan dengan apa yang seharusnya terjadi dengan maksud untuk secepatnya diambil tindakan korektif yang diperlukan. Menurut (Handoko, 2015) pengawasan merupakan suatu proses untuk menjaga agar tujuan-tujuan organisasi dan manajemen tercapai. Selanjutnya menurut (Kadarisman, 2013) pengawasan merupakan salah satu fungsi manajemen yaitu untuk menjaga agar pelaksanaan tugas, fungsi, dan wewenang tidak menyimpang dari aturan yang telah ditetapkan dalam rangka mencapai tujuan organisasi. Sedangkan menurut (Situmeang, 2017) mengemukakan bahwa pengawasan merupakan suatu proses atau langkah pencegahan apabila terjadi penyimpangan-penyimpangan kecil yang dilakukan oleh karyawan dalam pelaksanaan kegiatan organisasi serta menjamin tujuan-tujuan organisasi dapat tercapai sesuai yang direncanakan sebelumnya.

Berdasarkan teori diatas maka dapat disimpulkan pengawasan adalah suatu proses pemeriksaaan untuk memastikan bahwa segala aktifitas yang terlaksana sesuai dengan apa yang telah direncanakan.

\section{Indikator Pengawasan}

Indikator merupakan karakteristik, ciri-ciri dan ukuran dari suatu objek atau aktivitas. Indikator pengawasan bermakna ukuran dari pengawasan yang dilakukan pimpinan terhadap karyawannya.

Menurut (Handoko, 2015), mengemukakan indikator pengawasan yang baik adalah:

1. Akurat.

2. Tepat waktu, informasi harus dikumpulkan.

3. Terpusat pada titik-titik pengawasan strategi.

4. Objektif dan menyeluruh.

5. Realistik secara ekonomis.

6. Realistik secara organisasional.

7. Terkoordinasi dengan aliran kerja organisasi.

8. Fleksibel.

9. Bersifat sebagai petunjuk dan operasional

10. Diterima para anggota organisasi. 


\section{Kepemimpinan}

Kepemimpinan adalah suatu perilaku dengan tujuan tertentu untuk mempengaruhi aktivitas para anggota kelompok untuk mencapai tujuan bersama yang dirancang untuk memberikan manfaat individu dan organisasi, sehingga dalam suatu organisasi kepemimpinan merupakan faktor yang sangat penting dalam menentukan pencapaian tujuan yang telah ditetapkan oleh organisasi. Menurut (Rivai, 2014) kepemimpinan pada dasarnya merupakan pola hubungan antara individu-individu yang menggunakan wewenang dan pengaruhnya terhadap kelompok orang agar bekerja bersama-sama untuk mencapai tujuan. Selanjutnya menurut (Sutrisno, 2010) kepemimpinan adalah suatu proses kegiatan seseorang untuk menggerakkan orang lain dengan memimpin, membimbing, mempengaruhi orang lain untuk melakukan sesuatu agar dicapai hasil yang diharapkan. Berdasarkan teori diatas maka dapat disimpulkan kepemimpinan adalah suatu proses untuk mempengaruhi dan memberikan contoh kepada bawahannya dalam upaya mencapai tujuan organisasi.

\section{Indikator Kepemimpinan}

Menurut (Handoko, 2013) indikator kepemimpinan adalah sebagai berikut:

1. Kemampuan

2. Kebutuhan

3. Kecerdasan

4. Ketegasan

5. Kepercayaan diri

6. Kreatif

\section{Motivasi Kerja}

Sumber daya manusia merupakan bagian penting dari kegiatan di perusahaan, sehingga kelangsungan kegiatan perusahaan juga bergantung pada dukungan dari sumber daya manusia yang berkualitas dan berkompeten. Untuk dapat meningkatkan kepuasan kerja karyawan dalam bekerja, maka perusahaan perlu memberikan motivasi yang efektif dan tepat sasaran kepada karyawan. Karyawan yang telah termotivasi dengan tepat, maka akan dengan kesadaran dan kemauan sendiri untuk bekerja lebih baik dan memberikan produktifitas kerja yang maksimal bagi kemajuan dan kepentingan perusahaan dalam mencapai tujuannya. Menurut (Sutrisno, 2010) motivasi adalah suatu bentuk pemberian atau penimbulan motif yang dapat diartikan sebagai hal atau keadaan menjadi motif. Jadi motivasi adalah sesuatu yang dapat menimbulkan semangat atau dorongan kerja. Menurut (Mangkunegara, 2014) seorang pimpinan harus memberikan perhatian pada karyawan tentang pentingnya tujuan dari suatu pekerjaan agar timbul minat karyawan terhadap pelaksanaan kerja, jika telah timbul minatnya maka hasratnya menjadi kuat untuk mengambil keputusan dan melakukan tindakan kerja dalam mencapai tujuan yang di harapkan, dengan demikian karyawan akan bekerja dengan motivasi tinggi dan merasa puas terhadap hasil kerjanya.

\section{Indikator Motivasi Kerja}

Indikator motivasi kerja menurut (Siagian, 2014) adalah:

1. Daya pendorong

2. Kemauan

3. Kerelaan

4. Keahlian 
5. Keterampilan

6. Tanggung jawab

7. Kewajiban

8. Tujuan

\section{METODOLOGI PENELITIAN}

Penelitian dilaksanakan mulai bulan Maret 2021 sampai dengan Agustus 2021, pendekatan penelitian kuantitatif dan asosiatif. Dimana dilihat dari jenis datanya maka penelitian ini menggunakan penelitian kuantitatif, namun apabila dilihat dari cara penjelasannya maka penelitian ini menggunakan penelitian asosiatif. Penelitian ini dilaksanakan di kantor Dinas Ketahanan Pangan Dan Peternakan Provinsi Sumatera Utara, Populasi dalam penelitian ini adalah seluruh pegawai yang terdapat pada kantor Dinas Ketahanan Pangan Dan Peternakan Provinsi Sumatera Utara berjumlah 210 orang. jumlah sampel dalam penelitian ini adalah sebanyak 68 orang pegawai Dinas Ketahanan Pangan Dan Peternakan Provinsi Sumatera Utara. Pengambilan sampel ini menggunakan metode Nonprobability Sampling dengan menggunakan teknik Insidental sampling. Teknik pengumpulan data dalam penelitian ini menggunakan teknik wawancara, studi dokumentasi, observasi, dan angket. Teknik analisis data dalam penelitian ini menggunakan Uji Analisis Regresi Liner Berganda, Uji Hipotesis (Uji t dan Uji F), dan Koefisien Determinasi. Pengolahan data dalam penelitian ini menggunakan program software SPSS (Statistic Package for the Social Sciens) versi 24.00.

\section{HASIL PENELITIAN DAN PEMBAHASAN}

Sebelum melakukan analisis regresi berganda terlebih dahulu dilakukan uji lolos kendala liner atau uji asumsi klasik. Tujuan dilakukannya uji asumsi klasik adalah untuk mengetahui Apakah suatu variabel bormal atau tidak. Normal disini dalam arti mempunyai distribusi data yang normal. Normal atau tidaknya data berdasarkan patokan distribusi normal data dengan mean dan standar deviasi yang sama. Jadi asumsi klasik pada dasarnya memiliki kriteria-kriteria sebagai berikut.

Uji normalitas dilakukan untuk mengetahui Apakah variabel dalam sebuah model regresi, yaitu variabel terikat dan variabel bebas berdistribusi secara normal atau tidak.

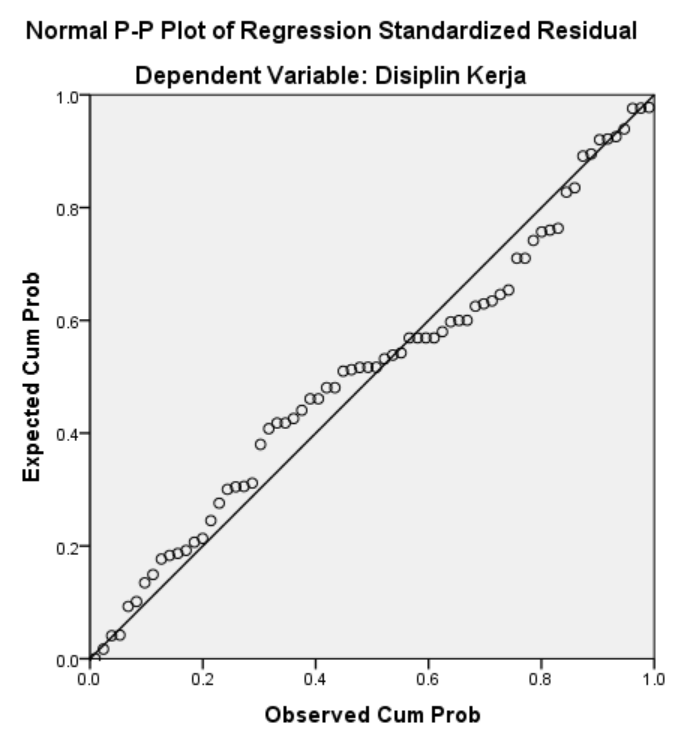

Sumber: Data diolah SPSS versi 24.0

Gambar 1 Hasil Uji Normalitas 
Pada grafik normal p-plot terlihat pada gambar diatas bahwa pola grafik normal terlihat dari tititk-titik yang menyebar disekitar garis diagonal dan penyebarannya mengikuti arah garis diagonal, maka dapat disimpulkan bahwa model regresi telah memenuhi asumsi normalitas.

Tabel 1. Hasil Uji Multikolonieritas

\begin{tabular}{|c|c|c|c|c|c|c|c|c|}
\hline \multicolumn{9}{|c|}{ Coefficients $^{a}$} \\
\hline \multirow{2}{*}{\multicolumn{2}{|c|}{ Model }} & \multicolumn{2}{|c|}{$\begin{array}{l}\text { Unstandardized } \\
\text { Coefficients }\end{array}$} & \multirow{2}{*}{$\begin{array}{c}\text { Standardized } \\
\text { Coefficients } \\
\text { Beta } \\
\end{array}$} & \multirow[b]{2}{*}{$\mathrm{t}$} & \multirow[b]{2}{*}{ Sig. } & \multicolumn{2}{|c|}{$\begin{array}{l}\text { Collinearity } \\
\text { Statistics }\end{array}$} \\
\hline & & $\mathrm{B}$ & Std. Error & & & & Tolerance & VIF \\
\hline 1 & (Constant) & -2.201 & 1.330 & & -1.655 & .103 & & \\
\hline & Pengawasan & .076 & .035 & .162 & 2.174 & .033 & .194 & 4.167 \\
\hline & $\begin{array}{l}\text { Kepemimpina } \\
\mathrm{n}\end{array}$ & .099 & .049 & .172 & 1.998 & .050 & .145 & 4.899 \\
\hline & Motivasi Kerja & .363 & .062 & .656 & 5.833 & .000 & .185 & 4.791 \\
\hline
\end{tabular}

a. Dependent Variable: Disiplin Kerja

Sumber: Data diolah SPSS versi 24.00

Dari tabel 1 dapat dilihat bahwa variabel pengawasan memiliki nilai tolerance sebesar $0.194>0.10$ dan nilai VIF sebesar $4.167<5$. Variabel kepemimpinan memiliki nilai tolerance sebesar $0.145>0.10$ dan nilai VIF sebesar $4.899<5$. Variabel motivasi kerja memiliki nilai tolerance sebesar $0.185>0.10$ dan nilai VIF sebesar $4.791<5$. Dari masing-masing variabel memiliki nilai tolerance $>0.1$ dan nilai $\mathrm{VIF}<5$, dengan demikian dapat disimpulkan bahwa tidak terjadi gejala multikolinearitas dalam penelitian ini.

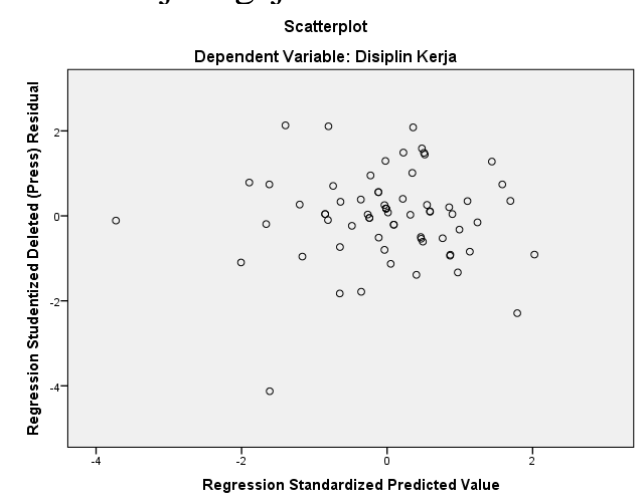

Sumber: Data diolah SPSS versi 24.00

Gambar 2. Hasil Uji Heteroskedastisitas

Berdasarkan gambar 2 diatas, dapat diketahui bahwa data (titik-titik) menyebar secara merata diatas dan dibawah garis nol, tidak berkumpul di satu tempat, serta tidak membentuk satu pola tertentu sehingga dapat disimpulkan bahwa pada uji regresi ini tidak terjadi heterokedastisitas.

Tabel 2. Hasil Regresi Linier Berganda

\begin{tabular}{|c|c|c|c|c|c|c|}
\hline \multicolumn{7}{|c|}{ Coefficients $^{a}$} \\
\hline \multirow{2}{*}{\multicolumn{2}{|c|}{ Model }} & \multicolumn{2}{|c|}{ Unstandardized Coefficients } & \multirow{2}{*}{$\begin{array}{c}\text { Standardized } \\
\text { Coefficients } \\
\text { Beta }\end{array}$} & \multirow[b]{2}{*}{$\mathrm{t}$} & \multirow[b]{2}{*}{ Sig. } \\
\hline & & $\mathrm{B}$ & Std. Error & & & \\
\hline \multirow[t]{4}{*}{1} & (Constant) & -2.201 & 1.330 & & -1.655 & .103 \\
\hline & Pengawasan & .076 & .035 & .162 & 2.174 & .033 \\
\hline & Kepemimpinan & .099 & .049 & .172 & 1.998 & .050 \\
\hline & Motivasi Kerja & .363 & .062 & .656 & 5.833 & .000 \\
\hline
\end{tabular}

a. Dependent Variable: Disiplin Kerja

Sumber: Data diolah SPSS versi 24.00 
Dari tabel 7 diatas diketahui nilai-nilai sebagai berikut :

1. Konstanta

2. Pengawasan

3. Kepemimpinan

4. Motivasi kerja

$$
\begin{aligned}
& =-2,201 \\
& =0,076 \\
& =0,099 \\
& =0,363
\end{aligned}
$$

Hasil tersebut dimasukkan kedalam persamaan regresi linier berganda sehingga diketahui persamaan berikut :

$$
Y=-2,201+0,076 X_{1}+0,099 X_{2}+0,363 X_{3}
$$

Jadi persamaan diatas bermakna jika :

1. Konstanta sebesar -2,201 menunjukkan bahwa apabila semua variabel independen pengawasan, kepemimpinan dan motivasi kerja diasumsikan bernilai nol, maka nilai dari disiplin kerja adalah sebesar -2201

2. Nilai koefisien regresi pengawasan sebesar 0,076 menunjukkan bahwa apabila nilai variabel pengawasan miningkat sebesar satu satuan, maka disiplin kerja meningkat sebesar 0,076 satuan dengan asumsi variabel independen lainnya bernilai nol

3. Nilai koefisien regresi kepemimpinan sebesar 0,099 menunjukkan bahwa apabila nilai variabel kepemimpinan miningkat sebesar satu satuan, maka disiplin kerja meningkat sebesar 0,099 satuan dengan asumsi variabel independen lainnya bernilai nol.

4. Nilai koefisien regresi motivasi kerja sebesar 0,363 menunjukkan bahwa apabila nilai variabel motivasi kerja miningkat sebesar satu satuan, maka disiplin kerja meningkat sebesar 0,363 satuan dengan asumsi variabel independen lainnya bernilai nol.

\section{Pengujian Hipotesis}

Uji t digunakan dalam penelitian ini digunakan untuk mengetahui kemampuan

\begin{tabular}{|c|c|c|c|c|c|c|}
\hline \multicolumn{7}{|c|}{ Coefficients $^{a}$} \\
\hline \multirow{2}{*}{\multicolumn{2}{|c|}{ Model }} & \multicolumn{2}{|c|}{ Unstandardized Coefficients } & \multirow{2}{*}{$\begin{array}{c}\text { Standardized } \\
\text { Coefficients } \\
\text { Beta }\end{array}$} & \multirow[b]{2}{*}{$\mathrm{t}$} & \multirow[b]{2}{*}{ Sig. } \\
\hline & & $\mathrm{B}$ & Std. Error & & & \\
\hline \multirow[t]{4}{*}{1} & (Constant) & -2.201 & 1.330 & & -1.655 & .103 \\
\hline & Pengawasan & .076 & .035 & .162 & 2.174 & .033 \\
\hline & Kepemimpinan & .099 & .049 & .172 & 1.998 & .050 \\
\hline & Motivasi Kerja & .363 & .062 & .656 & 5.833 & .000 \\
\hline
\end{tabular}
dari masing-masing variabel independen. Alasan lain uji t dilakukan untuk menguji apakah variabel bebas $(\mathrm{X})$ secara parsial atau individual mempunyai hubungan signifikan atau tidak terhadap variabel terikat (Y).

Tabel 3. Hasil Uji t

\section{Sumber : SPSS 24.00}

Hasil pengujian statistik pada tabel diatas dapat dijelaskan sebagai berikut:

\section{Pengaruh Pengawasan (X1) Terhadap Disiplin Kerja (Y)}

Nilai $t_{\text {hitung }}$ untuk variabel pengawasan adalah 2,174 dan $t_{\text {tabel }}$ dengan $\alpha=5 \%$ diketahui sebesar 1,997 dengan demikian $t_{\text {hitung }}$ lebih besar dari $t_{\text {tabel }}$ dan nilai signifikan pengawasan sebesar $0.033<0.05$ artinya dari hasil tersebut didapat kesimpulan bahwa $\mathrm{H}^{0}$ ditolak ( $\mathrm{H}^{\mathrm{a}}$ diterima) menunjukkan bahwa pengawasan berpengaruh signifikan terhadap disiplin kerja pada kantor Dinas Ketahanan Pangan Dan Peternakan Provinsi Sumatera Utara. 


\section{Pengaruh Kepemimpinan (X2) Terhadap Disiplin Kerja (Y)}

Nilai $t_{\text {hitung }}$ untuk variabel kepemimpinan adalah 1,998 dan $t_{\text {tabel }}$ dengan $\alpha=5 \%$ diketahui sebesar 1,997 dengan demikian $t_{\text {hitung }}$ lebih besar dari $t_{\text {tabel }}$ dan nilai signifikan pengawasan sebesar $0.050 \leq 0.05$ artinya dari hasil tersebut didapat kesimpulan bahwa $\mathrm{H}^{0}$ ditolak ( $\mathrm{H}^{\mathrm{a}}$ diterima) menunjukkan bahwa kepemimpinan berpengaruh signifikan terhadap disiplin kerja pada kantor Dinas Ketahanan Pangan Dan Peternakan Provinsi Sumatera Utara.

\section{Pengaruh Motivasi Kerja (X3) Terhadap Disiplin Kerja (Y)}

Nilai $t_{\text {hitung }}$ untuk variabel motivasi kerja adalah 5,833dan $\mathrm{t}_{\text {tabel }}$ dengan $\alpha=5 \%$ diketahui sebesar 1,997 dengan demikian $t_{\text {hitung }}$ lebih besar dari $t_{\text {tabel }}$ dan nilai signifikan pengawasan sebesar $0.000<0.05$ artinya dari hasil tersebut didapat kesimpulan bahwa $\mathrm{H}^{0}$ ditolak ( $\mathrm{H}^{\mathrm{a}}$ diterima) menunjukkan bahwa motivasi kerja berpengaruh signifikan terhadap disiplin kerja pada kantor Dinas Ketahanan Pangan Dan Peternakan Provinsi Sumatera Utara.

Tabel 4. Hasil Uji Koefisien Determinasi

\begin{tabular}{|c|c|c|c|c|}
\hline \multicolumn{5}{|c|}{ Model Summary } \\
\hline Model & $\mathrm{R}$ & R Square & Adjusted R Square & $\begin{array}{l}\text { Std. Error of the } \\
\text { Estimate }\end{array}$ \\
\hline 1 & $.965^{\mathrm{a}}$ & .931 & .928 & .95378 \\
\hline \multicolumn{5}{|c|}{ a. Predictors: (Constant), Motivasi Kerja, Pengawasan, Kepemimpinan } \\
\hline \multicolumn{5}{|c|}{ b. Dependent Variable: Disiplin Kerja } \\
\hline
\end{tabular}

Sumber: SPSS versi 24

$\mathrm{D}=\mathrm{R}^{2} \mathrm{X} 100 \%$

$\mathrm{D}=0.929 \times 100 \%$

$$
=92,9 \%
$$

Berdasarkan tabel diatas dapat dilihat bahwa nilai dari R square sebesar 0.931 yang berarti 93,1 dan hal ini menyatakan bahwa variabel pengawasan, kepemimpinan dan motivasi kerja sebesar 93,1\% untuk mempengaruhi variabel disiplin kerja. Selanjutnya selisih $100 \%-93,1 \%=6,9 \%$. hal ini menujukkan $6,9 \%$ tersebut adalah variabel lain yang tidak berkontribusi terhadap penelitian disiplin kerja.

\section{PEMBAHASAN}

\section{Pengaruh Pengawasan Terhadap Disiplin Kerja}

Berdasarkan penelitian yang diperoleh mengenai pengaruh pengawasan terhadap disiplin kerja pada pada kantor Dinas Ketahanan Pangan Dan Peternakan Provinsi Sumatera Utara hasil uji hipotesis secara parsial menunjukkan bahwa nilai $t_{\text {hitung }}$ untuk variabel pengawasan adalah 2,174 dan $t_{\text {tabel }}$ dengan $\alpha=5 \%$ diketahui sebesar 1,997 dengan demikian $t_{\text {hitung }}$ lebih besar dari $t_{\text {tabel }}$ dan nilai signifikan pengawasan sebesar $0.033<0.05$ artinya dari hasil tersebut didapat kesimpulan bahwa H0 ditolak (Ha diterima) menunjukkan bahwa pengawasan berpengaruh signifikan terhadap disiplin kerja pada kantor Dinas Ketahanan Pangan Dan Peternakan Provinsi Sumatera Utara.

Pengawasan yang efektif menuntut tingkat kepemimpinan yang tinggi meliputi pembentukan moral, mengembangkan kerjasama, kemampuan menanamkan disiplin dan mengenai sifat-sifat manusia. Hal ini disebabkan karena pimpinan mempunyai pengaruh yang besar dalam menegakkan disiplin bawahan. Kaitan antara pengawasan dengan disiplin kerja pegawai. Pengawasan adalah salah satu fungsi manajemen, yang merupakan 
kegiatan proses pimpinan untuk memastikan dan menjamin bahwa tujuan dan sasaran serta tugas-tugas organisasi akan dan telah terlaksana dengan baik sesuai dengan rencana, kebijaksanaan, instruksi dan ketentuan-ketentuan yang telah ditetapkan dan yang berlaku Disiplin tidak mungkin ada tanpa pengawasan yang baik, pemimpin harus mempunyai sistem pengawasan yang ia perlukan untuk mengarahkan para bawahannya dengan tepat. Berdasarkan uraian diatas dapatlah disimpulkan bahwa untuk menegakkan disiplin kerja maka pengawasan sangatlah diperlukan. Karena dengan adanya pengawasan maka para karyawan diharapkan akan dapat berbuat dan bertingkah laku sesuai dengan yang diinginkan oleh organisasi, yang ada pada akhirnya akan menentukan pencapaian tujuan yang telah ditentukan sebelumnya. Jadi pengawasan haruslah diarahkan pada upaya mewujudkan suasana tertib dan berdisiplin, yang tumbuh dan berkembang atas kesadaran dalam dirinya sendiri, (Sigar et al., 2018). Hasil penelitian ini sejalan dengan hasil penelitian terdahulu yang dilakukan oleh (Rizal \& Radiman, 2019), (Jufrizen, 2016) (Meika et al., 2017) dan (Sigar et al., 2018) yang menyimpulkan bahwa pengawasan memiliki pengaruh yang signifikan terhadap disiplin kerja pegawai.

\section{Pengaruh Kepemimpinan Terhadap Disiplin Kerja}

Berdasarkan penelitian yang diperoleh mengenai pengaruh kepemimpinan terhadap disiplin kerja pada pada kantor Dinas Ketahanan Pangan Dan Peternakan Provinsi Sumatera Utara hasil uji hipotesis secara parsial menunjukkan bahwa Nilai $t_{\text {hitung }}$ untuk variabel kepemimpinan adalah 1,998 dan $t_{\text {tabel }}$ dengan $\alpha=5 \%$ diketahui sebesar 1,997 dengan demikian $t_{\text {hitung }}$ lebih besar dari $t_{\text {tabel }}$ dan nilai signifikan pengawasan sebesar $0.050 \leq 0.05$ artinya dari hasil tersebut didapat kesimpulan bahwa $\mathrm{H}^{0}$ ditolak ( $\mathrm{H}^{\mathrm{a}}$ diterima) menunjukkan bahwa kepemimpinan berpengaruh signifikan terhadap disiplin kerja pada kantor Dinas Ketahanan Pangan Dan Peternakan Provinsi Sumatera Utara. Kepemimpinan merupakan motor penggerak bagi seluruh sumber daya yang ada di dalam suatu organisasi. Keberlangsungan hidup organisasi ditentukan oleh kualitas kepemimpinan, semakin berkualitas pemimpin perusahaan, maka disiplin karyawan akan semakin membaik.

Disiplin kerja merupakan kesediaan untuk mematuhi peraturan / ketentuan yang berlaku dalam lingkungan kerja masing-masing sehingga diharapkan dapat meningkatkan hasil kerja yang tinggi yang menunjukkan ketaan karyawan terhadap peraturan perusahaan. Pimpinan yang mampu menjalankan tugas dengan baik dan membina hubungan dengan karyawan lain akan lebih efektif dalam pencapaian tugas sehari-hari. Pembentukan perilaku disiplin dipengaruhi oleh faktor kepribadian dan faktor lingkungan yaitu kualitas kepemimpinan, kesejahteraan dan sistem penghargaan. Seorang pimpinan dikatakan efektif dan berkualitas dalam kepemimpinannya, jika para bawahannya berdisiplin baik. Untuk memelihara dan meningkatkan kedisiplinan yang baik adalah hal yang sulit, karena banyak faktor yang mempengaruhinya (Setiyani, 2015)

Hasil penelitian ini sejalan dengan hasil penelitian terdahulu yang dilakukan oleh (Rizal \& Radiman, 2019) (Susanty \& Baskoro, 2012), dan (Mahendra \& Brahmasari, 2014) yang menyimpulkan bahwa kepemimpinan memiliki pengaruh yang signifikan terhadap disiplin kerja pegawai.

\section{Pengaruh Motivasi Kerja Terhadap Disiplin Kerja}

Berdasarkan penelitian yang diperoleh mengenai pengaruh motivasi kerja terhadap disiplin kerja pada pada kantor Dinas Ketahanan Pangan Dan Peternakan Provinsi Sumatera Utara hasil uji hipotesis secara parsial menunjukkan bahwa Nilai 
$t_{\text {hitung }}$ untuk variabel motivasi kerja adalah 5,833dan $t_{\text {tabel }}$ dengan $\alpha=5 \%$ diketahui sebesar 1,997 dengan demikian $t_{\text {hitung }}$ lebih besar dari $t_{\text {tabel }}$ dan nilai signifikan pengawasan sebesar $0.000<0.05$ artinya dari hasil tersebut didapat kesimpulan bahwa $\mathrm{H}^{0}$ ditolak ( $\mathrm{H}^{\mathrm{a}}$ diterima) menunjukkan bahwa motivasi kerja berpengaruh signifikan terhadap disiplin kerja pada kantor Dinas Ketahanan Pangan Dan Peternakan Provinsi Sumatera Utara.

Motivasi kerja yang dimiliki kesuksesan dan keberhasilan hidup seseorang akan dapat diprediksikan. Individu yang semangat biasanya selalu bersikap optimis dan yakin akan kemampuannya dalam melakukan sesuatu. Sebalikya, individu yang rasa percaya dirinya rendah akan mengalami hambatan-hambatan dalam hidupnya, baik dalam berinteraksi dengan individu lain maupun dalam pekerjaan. Salah satu faktor untuk meningkatkan disiplin kerja adalah motivasi. Pada dasarnya suatu perusahaan bukan saja mengharapkan karyawan mau dan mampu bekerja secara giat, tetapi bagaimana memiliki motivasi yang tinggi untuk mencapai tujuan organisasi, kemampuan, kecakapan dan keterampilan karyawan tidak artinya apabila tidak diikuti dengan motivasi yang tinggi dari setiap karyawan guna meningkatkan disiplin kerja

Motivasi adalah pemberian atau penimbulan motif atau dapat pula diartikan sebagai hal atau keadaan menjadi motif. Jadi motivasi adalah sesuatu yang menimbulkan semangat atau dorongan kerja. (Sutrisno, 2010). Hasil penelitian ini sejalan dengan hasil penelitian terdahulu yang dilakukan oleh (Rizal \& Radiman, 2019) dan (Susanty \& Baskoro, 2012) yang menyimpulkan bahwa motivasi memiliki pengaruh yang signifikan terhadap disiplin kerja pegawai.

\section{KESIMPULAN}

Hasil penelitian dan pembahasan yang telah dikemukakan sebelumnya maka dapat diambil kesimpulan adalah sebagai berikut.

1. Berdasarkan hasil penelitian menunjukkan bahwa secara parsial pengawasan berpengaruh signifikan terhadap Disiplin Kerja Pegawai kantor Dinas Ketahanan Pangan Dan Peternakan Provinsi Sumatera Utara.

2. Berdasarkan hasil penelitian menunjukkan bahwa secara parsial kepemimpinan berpengaruh signifikan terhadap Disiplin Kerja Pegawai kantor Dinas Ketahanan Pangan Dan Peternakan Provinsi Sumatera Utara.

3. Berdasarkan hasil penelitian menunjukkan bahwa secara parsial motivasi kerja berpengaruh signifikan terhadap Disiplin Kerja Pegawai kantor Dinas Ketahanan Pangan Dan Peternakan Provinsi Sumatera Utara.

\section{DAFTAR PUSTAKA}

Afandi, P. (2016). Concept \& Indicator Human Resources Management. Deepublish.

Handoko, T. H. (2013). Manajemen Personalia dan Sumber Daya Manusia. BPFE Yogyakarta.

Handoko, T. H. (2015). Manajemen. BPEE.

Hasibuan, M. P. (2016). Manajemen Sumber Daya Manusia. Bumi Aksara.

Jufrizen, J. (2016). Pengaruh Pengawasan Terhadap Kinerja Karyawan Melalui Disiplin Kerja Pada PT. Socfin Indonesia Medan. Jurnal Ilmiah Manajemen Dan Bisnis, 17(2), 181-195.

Kadarisman, N. (2013). Manajemen Pengembangan Sumber Daya Manusia. PT. Raja Grafindo Persada.

Kartono, K. (2015). Pemimpin dan Kepemimpinan. PT. Raja Grafindo Persada. 
Mahendra, I. G. N. T., \& Brahmasari, I. A. (2014). Pengaruh Kepemimpinan Terhadap Disiplin Kerja, Motivasi Kerja Dan Kinerja Perawat Pelaksana Di Ruang Rawat Inap RSJ Menur Surabaya. Jurnal Ilmu Ekonomi \& Studi, 1(1), 22-42.

Mangkunegara, A. A. (2014). Evaluasi Kinerja Sumber Daya Manusia. Refika Aditama.

Meika, I., Purnmo, R. E., \& Wahjuni, S. (2017). Pengaruh Pengawasan terhadap Disiplin Kerja Karyawan pada Koperasi Margo Mulyo Ambulu, Kabupaten Jember. ESospol, 4(1), 56-61.

Risma, N., Nurhalifah, \& Saleh. (2018). Pengaruh Pengawasan Terhadap Disiplin Kerja Pegawai Di SMK Negeri 1 Gowa. Jurnal Pendidikan Administrasi Perkantoran, 1(1), 1-13.

Rivai, V. (2014). Manajemen Sumber Daya Manusia Untuk Perusahaan. PT. Raja Grafindo Persada.

Rizal, S. M., \& Radiman, R. (2019). Pengaruh Motivasi, Pengawasan, dan Kepemimpinan Terhadap Disiplin Kerja Pegawai. Maneggio: Jurnal Ilmiah Magister Manajemen, 2(1), 117-128.

Robbins, S. P. (2012). Perilaku Organisasi. PT. Indeks Kelompok Gramedia.

Setiyani, F. (2015). Pengaruh Kepemimpinan Dan Pengawasan Terhadap Disiplin Kerja Security PT. Karya Satria Abadi Pekanbaru. Jom FEKON, 2(1), 1-15.

Siagian, S. P. (2014). Manajemen dan Evaluasi Kinerja. Bumi Aksara.

Sigar, J. A. B., Sambul, S. A. P., \& Asaloei, S. (2018). Pengaruh Pengawasan Terhadap Disiplin Kerja Karyawan pada Hotel Sintesa Peninsula Manado. Jurnal Administrasi Bisnis, 6(3), 53-60.

Situmeang, R. S. (2017). engaruh Pengawasan Dan Pengalaman Kerja Terhadap Kinerja Karyawan Pada PT. Mitra Karyawa Anugrah. Journal Of Innovation And Entrepreneurship, 2(2), 148-160.

Susanty, A., \& Baskoro, S. W. (2012). Pengaruh Motivasi Kerja dan Gaya Kepemimpinan Terhadap Disiplin Kerja Karyawan (Studi Kasus Pada PT. PLN (Persero) APD Semarang). Jurnal TI Undip, 7(2), 77-84.

Sutrisno, E. (2010). Manajemen Sumber Daya Manusia. Erlangga. 